\title{
High honeybee abundances reduce wild bee abundances on flowers in the city of Munich
}

\author{
Susanne S. Renner ${ }^{1}$ (D) $\cdot$ Marie Sophie Graf ${ }^{1} \cdot$ Zoe Hentschel $^{1} \cdot$ Helen Krause $^{1} \cdot$ Andreas Fleischmann $^{2}$
}

Received: 25 September 2020 / Accepted: 14 January 2021 / Published online: 7 February 2021

(c) The Author(s) 2021

\begin{abstract}
The increase in managed honeybees (Apis mellifera) in many European cities has unknown effects on the densities of wild bees through competition. To investigate this, we monitored honeybees and non-honeybees from 01 April to 31 July 2019 and 2020 at 29 species of plants representing diverse taxonomic and floral-functional types in a large urban garden in the city of Munich in which the same plant species were cultivated in both years. No bee hives were present in the focal garden, and all bee hives in the adjacent area were closely monitored by interviewing the relevant bee keepers in both 2019 and 2020 . Honeybee numbers were similar in April of both years, but increased from May to July 2020 compared to 2019. The higher densities correlated with a significant increase in shifts from wild bee to honeybee visits in May/June/July, while visitor spectra in April 2019 and 2020 remained the same. Most of the species that experienced a shift to honeybee visits in 2020 were visited mostly or exclusively for their nectar. There were no shifts towards increased wild bee visits in any species. These results from a flower-rich garden have implications for the discussion of whether urban bee keeping might negatively impact wild bees. We found clear support that high honeybee densities result in exploitative competition at numerous types of flowers.
\end{abstract}

Keywords Exploitative competition · Honeybees · Wild bees · Resource consumption · Urban bee keeping

\section{Introduction}

It is notoriously difficult to provide unambiguous evidence of competition, particularly in mobile organisms (Goulson 2003). Because of this there is no clear agreement whether increased honeybee densities have a negative impact on wild bee diversity or abundance via exploitative competition for nectar and pollen (Gunnarsson and Federsel 2014; Lindström et al. 2016; Geslin 2017; Mallinger et al. 2017; Wojcik et al. 2018). Most studies so far have focused on agricultural settings to address the question of resource overlap and competition between honeybees and wild bees. In Central Europe, however, cities are now a refuge for several

Communicated by Nina Farwig.

Susanne S. Renner

renner@lmu.de

1 Systematic Botany and Mycology, University of Munich (LMU), Menzinger Str. 67, 80638 Munich, Germany

2 Botanische Staatssammlung München, Menzinger Str. 67, 80638 Munich, Germany species of wild bees (Sirohi et al. 2015; Banaszak-Cibicka et al. 2018; Hofmann et al. 2019), and some have higher bee diversities than similarly-sized arable areas or forest, probably because of high plant diversity, longer-lasting flowering season, and near-absence of pesticides and herbicides.

The new role of cities as refugia for wild bees raises the question whether the current increase in urban honeybee keeping (Lorenz and Stark 2015) might negatively impact wild bees in cities by depleting their nectar and/or pollen resources. The question is difficult to answer, because the European dark honeybee (Apis mellifera mellifera) is a native European species that has coexisted with European wild bee species for thousands of years (Dams 1978) during which time both groups simultaneously had to cope with numerous changes in flower abundances and local climate. To detect significant ongoing changes in foraging competition between honeybees and wild bees, data are required from settings in which the abundances of honeybees change, but those of floral resources and wild bee nesting sites do not.

Here we report such data from two flowering seasons in a botanical garden in an urban setting in which it was possible 
to monitor wild bee and honeybee visits in a wide range of plant species. The plants were studied at the same locations and with the same methods in both years (during short intervals distributed over numerous sunny days for a total of about $9 \mathrm{~h} /$ species), and honeybee numbers were estimated by monitoring all hives in the surrounding area and interviewing their owners. The expectation was that under food competition, increased honeybee densities at a particular flower species would shift the relative proportions of wild bees at that plant and time. The bee-rich garden in which our study was conducted contains no bee hives, so that all foraging honeybees come from the surrounding area (Hofmann et al. 2018; Hofmann and Renner 2020). This experimental set-up captures the situation in many European cities in which bees from hives on roofs and balconies forage in near-by parks, private gardens, or allotment gardens (Beckedorf 2015; Hofmann and Renner 2018; Wojcik et al. 2018). Given the lack of data on the effects of urban bee keeping on wild bees (Geslin 2017; Wojcik et al. 2018), we designed this study to help inform conservation and management measures in cities.

\section{Materials and methods}

The study took place in the Munich Botanic Garden from 01 April to 31 July 2019 and 2020. The garden opened in May 1914, covers about 21 hectares and borders on the 210-hectar-large Nymphenburg Palace Park at $48^{\circ} 09^{\prime} 45^{\prime \prime}$ $\mathrm{N}$ and $11^{\circ} 30^{\prime} 06^{\prime \prime} \mathrm{E}$, at $500 \mathrm{~m}$ above sea level. It is currently home to 106 bee species (including honeybee) whose abundances were scored in 2015-2017 by repeated monitoring walks (Hofmann et al. 2018). Several cavity nest boxes for solitary bees are located in the garden, but no honeybee hives have ever been placed there. The botanical garden provides a flower-rich habitat with thousands of native and cultivated species and varieties in flower beds and near-natural meadows throughout the year. Its layout of paths and beds is protected as a cultural monument, and all beds are watered and cared for by 44 gardeners, whose professional task and goal is to maintain a beautiful display of healthy plants all year long. Since 1795, 324 species of bees have been recorded from Munich (Hofmann and Renner 2020) and 123 from the Botanical Garden from 1997-2017 (79 species in 1997-1999, 106 in 2015-2017, with an overlap of 62 species; Bembé et al. 2001; Hofmann et al. 2018).

From 01 April until 31 July 2019 and 2020, we counted bees that alighted and foraged on the flowers of 14 species in April and May, and 15 species in June and July, one plant species (Nepeta mussinii) was observed in both April and May. Plants were observed at the same sites in both years and had the same distances to the surrounding honeybee hives in both years. Bees were counted during many 5-min intervals on 15-50 flowers or inflorescences for a total of about $9 \mathrm{~h}$ per species, with the number of flowers chosen so that all bees could be seen and counted with precision. Observations were only made during dry, sunny or at most slightly overcast days. Herbarium vouchers were made of each species and deposited in the Munich herbarium.

In both years, all four bee keepers in the Nymphenburg Palace park (S. Fritz, M. Högner, A. Kromer, and Mr. Kostrow) were interviewed about the health and size of their bee hives.

\section{Results}

In total, we observed 9.328 honeybees and 6.460 wild bees over $172 \mathrm{~h}$ in 2019 and 18.630 honeybees and 6.281 wild bees over $264 \mathrm{~h}$ at the same 29 plant species in 2020 (Table 1). The focal plants represented different taxonomic and floral-functional types (Fig. 1), including native species and horticultural forms, species adapted to bee pollination (e.g., the Lamiaceae Lavandula angustifolia, Leonurus cardiaca, Stachys byzantina; Asteraceae such as Taraxacum) as well as species pollinated by other insects, such as flies and butterflies, in their native habitats (e.g., Hyacinthus) or species in areas naturally devoid of honeybees (e.g., New World Dahlia, Echinacea, and Mahonia aquifolium). The species and densities of other flowering plants (not monitored for this study) present in the botanical garden in both years were similar. Honeybees were observed at all plant species (Table 1) and at all distances from the hives (Fig. 2). The resource overlap within the habitat, i.e., the percentage of plant species used by both honeybees and wild bees was almost complete, suggesting food competition. Two species, Helianthemum and Cotoneaster, in 2019 were visited by both wild bees and honeybees, but in 2020 only by honeybees (Table 1).

Twelve (41\%) of the 29 species were visited as pollen and nectar sources; five (17\%) were only pollen sources; and 11 (38\%) were only nectar sources. The only plant used differently in the two study years was Narcissus pseudonarcissus, which in 2019 was visited for both pollen and nectar, but in 2020 only for pollen. Two of the nine species (22\%) that experienced a shift in their visitor spectra in 2020 compared to 2019 were pollen-only sources, six $(67 \%)$ were nectaronly sources, and one (11\%) was exploited for both its pollen and nectar, implying that seven $(78 \%)$ of the species that experienced a shift to fewer wild bees in 2020 were visited for their nectar. 
Table 1 Plant species studied in spring and summer of 2019 and 2020 with their geographic origin and number of honeybees and wild bees per hour, and whether bees foraged for pollen and/or nectar

\begin{tabular}{|c|c|c|c|c|c|c|c|c|}
\hline \multirow{2}{*}{$\begin{array}{l}\text { Plant species and hours of obser- } \\
\text { vations and month }(2019 / 2020)\end{array}$} & \multirow[t]{2}{*}{ Geographic origin } & \multicolumn{2}{|c|}{ Honeybees/h } & \multicolumn{2}{|c|}{ Wild bees $/ \mathrm{h}$} & \multicolumn{2}{|l|}{ Nectar/pollen } & \multirow[t]{2}{*}{ Shif } \\
\hline & & 2019 & 2020 & 2019 & 2020 & 2019 & 2020 & \\
\hline \multicolumn{9}{|l|}{ April and May } \\
\hline $\begin{array}{l}\text { Allium schoenoprasum L. (6/10, } \\
\text { April) }\end{array}$ & Eurasia \& North America & 50 & 51 & 1 & 4 & Pollen and nectar & Pollen and nectar & \\
\hline $\begin{array}{l}\text { Aurinia saxatilis (L.) Desv. (6/9, } \\
\text { April) }\end{array}$ & $\begin{array}{l}\text { Central Europe, Southern } \\
\text { Europe, Asia Minor }\end{array}$ & 2 & 1 & 32 & 15 & Pollen and nectar & Pollen and nectar & \\
\hline $\begin{array}{l}\text { Cotoneaster horizontalis Decne. } \\
\text { (6/10, May) }\end{array}$ & Western China, Taiwan & 103 & 124 & 2 & 0 & Pollen & Pollen & $(\mathrm{X})$ \\
\hline $\begin{array}{l}\text { Erysimum allionii Kuntze } \\
\text { 'Orange' (6/10, May) }\end{array}$ & Greece & 64 & 52 & 5 & 6 & Pollen and nectar & Pollen and nectar & \\
\hline $\begin{array}{l}\text { Euonymus alatus (Thunb.) Sie- } \\
\text { bold (4/9, April) }\end{array}$ & Japan, Central China & 31 & 23 & 5 & 2 & Nectar & Nectar & \\
\hline $\begin{array}{l}\text { Hyacinthus orientalis L. hybrid } \\
\text { (5/10, April) }\end{array}$ & $\begin{array}{l}\text { Asia Minor, Middle East and SW } \\
\text { Asia }\end{array}$ & 52 & 35 & 2 & 5 & Pollen and nectar & Pollen and nectar & \\
\hline $\begin{array}{l}\text { Mahonia aquifolium } \\
\text { (Pursh) Nutt. (6/10, April) }\end{array}$ & Pacific America & 37 & 29 & 7 & 5 & Pollen and nectar & Pollen and nectar & \\
\hline $\begin{array}{l}\text { Malus baccata (L.) Borkh. var. } \\
\text { mandshurica (6/10, April) }\end{array}$ & $\begin{array}{l}\text { Central Japan, Central China, } \\
\text { Korea }\end{array}$ & 47 & 38 & 15 & 2 & Pollen and nectar & Pollen and nectar & \\
\hline $\begin{array}{l}\text { Muscari botryoides Mill. (8/9, } \\
\text { April) }\end{array}$ & $\begin{array}{l}\text { Central and Southern Europe, } \\
\text { Asia }\end{array}$ & 8 & 25 & 7 & 8 & Pollen and nectar & Pollen and nectar & \\
\hline $\begin{array}{l}\text { Narcissus pseudonarcissus L. } \\
\text { (6/1, April) }\end{array}$ & Western Europe & 4 & 1 & 14 & 7 & Pollen and nectar & Pollen & \\
\hline $\begin{array}{l}\text { Nepeta mussinii Spreng. ex } \\
\text { Henck. 'Superba' (6/10, } \\
\text { April) }\end{array}$ & Eastern Turkey, Northwest Iran & 7 & 8 & 35 & 26 & Pollen and nectar & Pollen and nectar & \\
\hline Nepeta mussinii (6/10, May) & Ditto & 76 & 84 & 7 & 53 & Pollen and nectar & Pollen and nectar & \\
\hline $\begin{array}{l}\text { Rhododendron 'Roselyn' (7/10, } \\
\text { May) }\end{array}$ & Himalayas & 40 & 12 & 52 & 49 & Pollen & Pollen & \\
\hline $\begin{array}{l}\text { Rubus fruticosus L. s.l (7/10, } \\
\text { May) }\end{array}$ & $\begin{array}{l}\text { Europe, North Africa, Asia, } \\
\text { North America }\end{array}$ & 78 & 113 & 15 & 11 & Pollen and nectar & Pollen and nectar & $(\mathrm{X})$ \\
\hline $\begin{array}{l}\text { Taraxacum sect. Taraxacum } \\
\text { (7/10, April) }\end{array}$ & Central Europe & 28 & 26 & 14 & 5 & Pollen and nectar & Pollen and nectar & \\
\hline \multicolumn{9}{|l|}{ June and July } \\
\hline $\begin{array}{l}\text { Brassica juncea (L.) Czern. (4/8, } \\
\text { June) }\end{array}$ & Western and Central Asia & 73 & 39 & 23 & 21 & Pollen and nectar & Pollen and nectar & \\
\hline Dahlia hybrid 'Fee' (7/10, July) & Mexico and Central America & 62 & 63 & 75 & 37 & Pollen and nectar & Pollen and nectar & \\
\hline $\begin{array}{l}\text { Echinacea purpurea (L.) Moench } \\
\text { (7/10, July) }\end{array}$ & North America & 60 & 55 & 37 & 12 & Nectar & Nectar & \\
\hline $\begin{array}{l}\text { Echinops banaticus Rochel \& } \\
\text { Borza (11/10, July) }\end{array}$ & Southeast Europe & 72 & 169 & 48 & 136 & Nectar & Nectar & \\
\hline $\begin{array}{l}\text { Echium vulgare L. (7/10, June/ } \\
\text { July) }\end{array}$ & Europe, Western Asia & 55 & 101 & 49 & 46 & Nectar & Nectar & \\
\hline $\begin{array}{l}\text { Erigeron glaucus KerGawl. } \\
\text { (8/10, June) }\end{array}$ & North America & 7 & 56 & 90 & 84 & Pollen & Pollen & \\
\hline Helianthemum hybrid (1/8, June) & Central Europe, Mediterranean & 169 & 91 & 6 & 0 & $\begin{array}{l}\text { Pollen (flow- } \\
\text { ershave no } \\
\text { netcar) }\end{array}$ & $\begin{array}{l}\text { Pollen (flowers } \\
\text { have no nectar) }\end{array}$ & \\
\hline $\begin{array}{l}\text { Heterotheca villosa (Pursh) Shin- } \\
\text { ners ( } 8 / 10, \text { June) }\end{array}$ & Mexico & 23 & 134 & 51 & 1 & Pollen & Pollen & $X$ \\
\hline $\begin{array}{l}\text { Lavandula angustifolia Mill. } \\
\text { (7/9, July) }\end{array}$ & Mediterranean & 74 & 132 & 51 & 22 & Nectar & Nectar & $X$ \\
\hline $\begin{array}{l}\text { Leonurus cardiaca L. (7/10, } \\
\text { July) }\end{array}$ & Central Asia, Southeast Europe & 53 & 67 & 43 & 8 & Nectar & Nectar & $\mathrm{X}$ \\
\hline
\end{tabular}


Table 1 (continued)

\begin{tabular}{|c|c|c|c|c|c|c|c|c|}
\hline \multirow{2}{*}{$\begin{array}{l}\text { Plant species and hours of obser- } \\
\text { vations and month }(2019 / 2020)\end{array}$} & \multirow[t]{2}{*}{ Geographic origin } & \multicolumn{2}{|c|}{ Honeybees/h } & \multicolumn{2}{|c|}{ Wild bees/h } & \multicolumn{2}{|c|}{ Nectar/pollen } & \multirow[t]{2}{*}{ Shift } \\
\hline & & 2019 & 2020 & 2019 & 2020 & 2019 & 2020 & \\
\hline Reseda alba L. (7/5, June) & Europe, Asia, North Africa & 26 & 49 & 100 & 18 & Nectar & Nectar & $\mathrm{X}$ \\
\hline $\begin{array}{l}\text { Salvia farinacea Benth. (5/10, } \\
\text { June/July) }\end{array}$ & Mexico, S USA & 9 & 23 & 41 & 6 & Nectar & Nectar & $X$ \\
\hline $\begin{array}{l}\text { Phedimus spurius (M.Bieb.) 't } \\
\text { Hart (6/10, July) }\end{array}$ & North America, Asia & 179 & 231 & 53 & 21 & Nectar & Nectar & $X$ \\
\hline $\begin{array}{l}\text { Stachys byzantina K.Koch (8/10, } \\
\text { June/July) }\end{array}$ & Asia Minor, Caucasus & 70 & 87 & 33 & 11 & Nectar & Nectar & $X$ \\
\hline $\begin{array}{l}\text { Symphytum officinale L. (2/10, } \\
\text { June) }\end{array}$ & Eurasia, Spain, China & 29 & 17 & 51 & 42 & Nectar & Nectar & \\
\hline
\end{tabular}

Also shown are resource use and if there is a shift in the proportions of honeybees to wild bees between 2019 and 2020, with weak shifts indicated by $(\mathrm{X})$ and strong shifts by $\mathrm{X}$

In April 2019 and 2020, honeybee densities remained identical (Table 2), but they increased from May to July 2020 compared to 2019 (Table 2). This increase correlated with significantly fewer wild bee visits in nine of the 20 May/June/July-flowering species, while visitor spectra did not change in the ten April-flowering species (Table 1, which shows 30 observations, because $N$. mussinii was observed in April and May; $\chi^{2}=6.43, d f=1, P=0.05$ ). All observed shifts in visitor spectra were in the direction of increased honeybee numbers (Table 1).

\section{Discussion}

Despite the large diversity and abundance of flowers available at our study site, a 21-hectar-large botanical garden, we found a significant negative relationship between the densities of honeybees and those of flower-visiting wild bees, almost regardless of flower type (Fig. 1; Tables 1, 2 ). That the higher resource depletion by foraging honeybees in May, June, and July 2020 compared to 2019 negatively affected the abundances of foraging wild bees, matches evidence that the experimental addition of honeybee colonies negatively impacts bumblebees that overlap with honeybees in resource use (Wojcik et al. 2018). Per year, a honeybee colony harvests $10-60 \mathrm{~kg}$ of pollen and $20-150 \mathrm{~kg}$ of honey, which translates to $5-9000 \mathrm{~kg}$ pollen and 10-22.500 kg honey/ $/ \mathrm{km}^{2} /$ year (Goulson 2003). These numbers suggest that honeybees must use a substantial proportion of floral resources at any one time and place, and as our data show (Table 1), food competition occurred not only at flowers providing both nectar (sugars) and pollen (protein) but also at flowers that provide only pollen. Bees are often more taxonomically restricted in their pollen collection than in their nectar collection (Cane and Sipes 2006); however, only $23 \%$ of 445 wild bees that occur in Germany (and for which data on pollen preferences are available) are pollen specialists (Hofmann et al. 2019). Most European wild bees are also much smaller than honeybees and have short average flight distances (Hofmann et al. 2020), which further decreases their ability to avoid competition by foraging at more distant plant populations.

Although our study demonstrates the depressing effects of increased honeybee densities on the simultaneous proportions of wild bees at flowers of the same species, we lack data on the fitness effects of this observation. It is plausible that in the summer of 2020, wild bees had to travel further and/or use less profitable flowers compared to 2019, but to determine whether this had non-trivial effects on their fitness would require competitive exclusion experiments combined with longer-term studies of wild bee populations. To our knowledge, no such study has been carried out (Steffan-Dewenter and Tscharntke 2000; Goulson 2003; Wojcik et al. 2018). That the visitor shifts observed in 2020 might instead have been due to lower abundances of wild bee species, or to higher or lower flower densities, seems implausible given the complete consistency of the direction of shifts (from wild bees to honeybees) throughout all three months with higher honeybee densities (Tables 1, 2) and the rich flower diversity and abundance in the botanical garden.

Based on the present results from a resource-rich urban garden, caution should be used when introducing high densities of Apis mellifera in cities. The city of Paris in 2018 harboured 7 hives $/ \mathrm{km}^{2}$, Berlin in 2014 had 6 hives $/ \mathrm{km}^{2}$, and Hamburg in the same year 5-6 hives $/ \mathrm{km}^{2}$ (Beckedorf 2015 ), with an increase in the latter two cities of $125 \%$ between 2007 and 2014. In our study area, the densities 

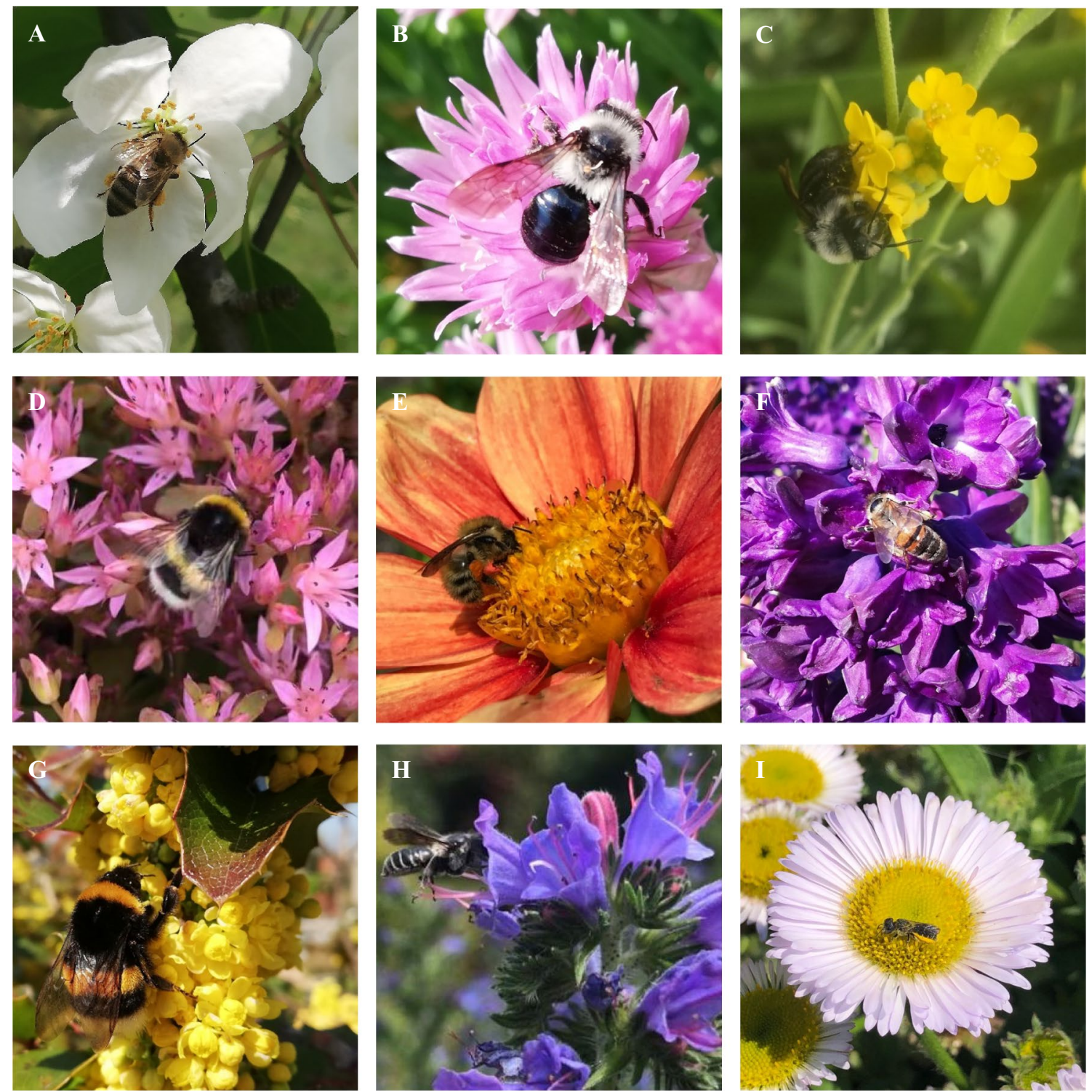

Fig. 1 Examples of plant and bee species monitored in this study. a Apis mellifera on Malus baccata, $\mathbf{b}$ Andrena cineraria on Allium schoenoprasum, c Andrena cineraria on Aurinia saxatilis, d Bombus lucorum s.l. on Phedimus spurius, e Bombus pascuorum on Dahlia hybrid 'Fee', f Apis mellifera on Hyacinthus orientalis hybrid, $\mathbf{g}$ Bombus terrestris on Mahonia aquifolium, h Hoplitis adunca on Echium vulgare , i Heriades truncorum on Erigeron glaucus

remain unchanged, strong food competition between honeybees and wild bees is likely and may have negative consequences for the persistence of wild bee populations in cities. 

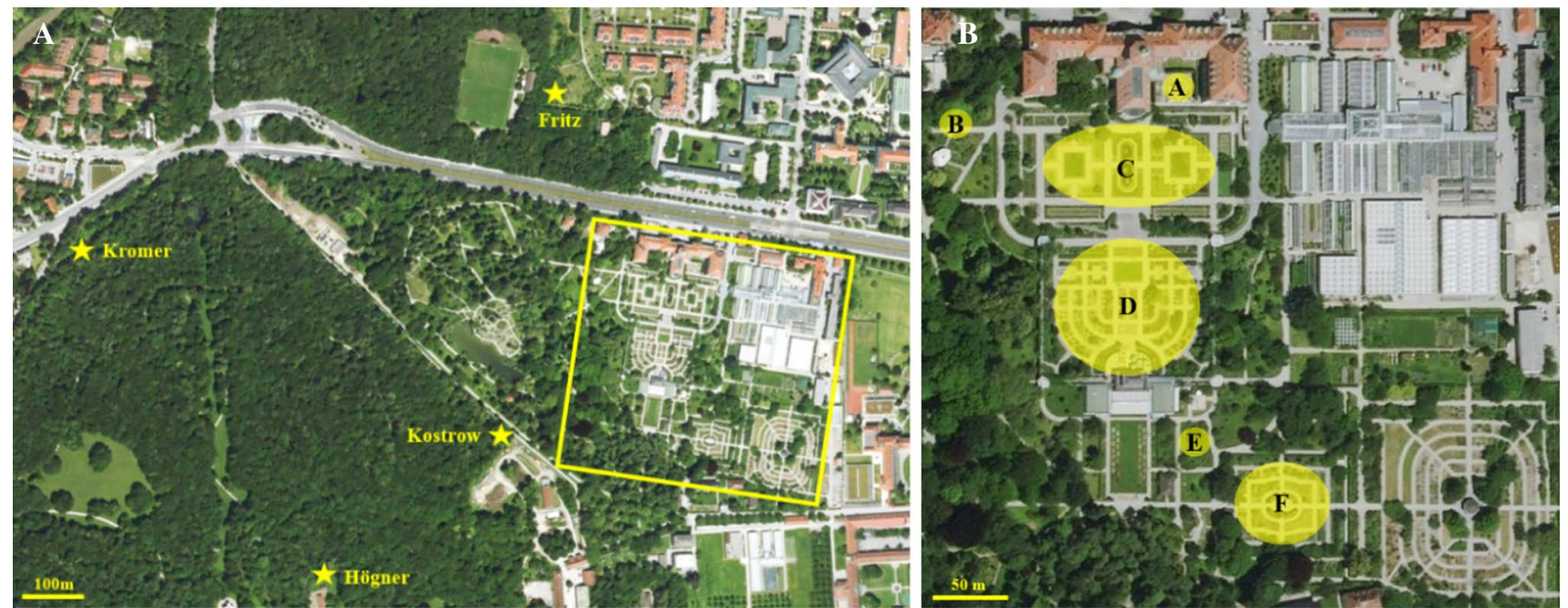

Fig. 2 Locations of bee hives and plant species monitored in this study. a Locations of the hives of the beekeepers Fritz, Kromer, Kostrow, and Högner. The Botanical Garden Munich is shown in the yellow square. In $\mathbf{b}$ the yellow square is enlarged. The letters A-F stand

Table 2 Honeybee hives near the botanical garden Munich in 2019 and 2020 (see Fig. 2 for the location of hives)

\begin{tabular}{lllll}
\hline Month & $\begin{array}{l}\text { Bee hives } \\
2019\end{array}$ & $\begin{array}{l}\text { Honey bees } \\
\text { 2019 (mil- } \\
\text { lions) }\end{array}$ & $\begin{array}{l}\text { Bee hives } \\
2020\end{array}$ & $\begin{array}{l}\text { Honeybees } \\
2020 \text { (mil- } \\
\text { lions) }\end{array}$ \\
\hline April & $\leq 33$ & $\leq 0.7-1.3$ & 33 & $0.7-1.3$ \\
May & $\leq 33$ & $\leq 0.7-1.3$ & 41 & $1.0-1.6$ \\
June & 33 & $0.7-1.3$ & $44 / 45$ & $1.3-1.8$ \\
July & 33 & $0.7-1.3$ & 44 & $1.3-1.9$ \\
\hline
\end{tabular}

The numbers of bees per hive were estimated by the four bee keepers who owned the hives ("Materials and methods"). The increase in June 2020 is due to natural reproduction (swarming of bees)

Acknowledgements We thank J. Gandlgruber, V. von Mitzlaff, A. Ruhland, and D. Weydert for bee counts in 2019 and two anonymous reviewers for their critical comments.

Author contribution statement SSR designed the study and wrote the first draft of the manuscript; MSG, ZH, and $\mathrm{HK}$ collected the data and did statistical tests; AF identified plants and bees; all authors worked on the final manuscript.

Funding Open Access funding enabled and organized by Projekt DEAL.

Open Access This article is licensed under a Creative Commons Attribution 4.0 International License, which permits use, sharing, adaptation, distribution and reproduction in any medium or format, as long as you give appropriate credit to the original author(s) and the source, provide a link to the Creative Commons licence, and indicate if changes were made. The images or other third party material in this article are for the locations of the 29 plant species numbers in Table 1 numbered continuously. A: plant no. 25; B: plant no. 14; C: plant nos. 2, 5, 6, 10, 11, 16, 22, 24, 26 and 28; D: plant nos. 3, 4, 7, 9, 12, 17, 18, 19, 20, 21, 23, 27 and 29; E: plant no. 8; and F: plant nos. 1, 13 and 15

included in the article's Creative Commons licence, unless indicated otherwise in a credit line to the material. If material is not included in the article's Creative Commons licence and your intended use is not permitted by statutory regulation or exceeds the permitted use, you will need to obtain permission directly from the copyright holder. To view a copy of this licence, visit http://creativecommons.org/licenses/by/4.0/.

\section{References}

Banaszak-Cibicka W, Twerd L, Fliszkiewicz M, Giejdasz K, Langowska A (2018) City parks vs. natural areas-is it possible to preserve a natural level of bee richness and abundance in a city park? Urban Ecosyst 21:599-613

Beckedorf S (2015) Der Boom hält an Deutsches Bienenjournal 23(11):6-7

Bembé B, Gerlach G, Schuberth J, Schönitzer K (2001) Die Wildbienen im Botanischen Garten München. Nachrichtenbl Bay Entomol 50:30-41

Dams LR (1978) Bees and honey-hunting scenes in the Mesolithic rock art of eastern Spain. Bee World 59:45-53

Cane JH, Sipes SS (2006) Characterizing floral specialization by bees: Analytical methods and a revised lexicon for oligolecty. In: Waser NM, Ollerton J (eds) Plant-pollinator interactions: from specialization to generalization. The University of Chicago Press, Chicago, pp 99-122

Geslin B (2017) Massively introduced managed species and their consequences for plant-pollinator interactions. Adv Ecol Res 57:147-199

Goulson D (2003) Effects of introduced bees on native ecosystems. Ann Rev Ecol Evol Syst 34:1-26

Gunnarsson B, Federsel LM (2014) Bumblebees in the city: abundance, species richness and diversity in two urban habitats. J Insect Conserv 18:1185-1191 
Hofmann MM, Renner SS (2018) Bee species recorded between 1992 and 2017 from green roofs in Asia, Europe, and North America, with key characteristics and open research questions. Apidologie (Celle) 49:307-313

Hofmann MM, Renner SS (2020) One-year-old flower strips already support a quarter of a city's bee species. J Hymenopt Res 75:87-95

Hofmann MM, Fleischmann A, Renner SS (2018) Changes in the bee fauna of a German botanical garden between 1997 and 2017, attributable to climate warming, not other parameters. Oecologia 187:701-706

Hofmann MM, Zohner CM, Renner SS (2019) Narrow habitat breath and late-summer emergence increase extinction vulnerability in Central European bees. Proc R Soc B 286:20190316. https://doi. org/10.1098/rspb.2019.0316

Hofmann MM, Fleischmann A, Renner SS (2020) Foraging distances in six species of solitary bees with body lengths of 6 to $15 \mathrm{~mm}$, inferred from individual tagging, suggest $150 \mathrm{~m}$-rule-of-thumb for flower strip distances. J Hymenopt Res 77:105-117

Lindström SAM, Herbertsson L, Rundlöf M, Bommarco R, Smith HG (2016) Experimental evidence that honeybees depress wild insect densities in a flowering crop. Proc R Soc B 283:20161641. https://doi.org/10.1098/rspb.2016.1641
Lorenz S, Stark K (2015) Saving the honeybees in Berlin? A case study of the urban beekeeping boom. Environ Sociol 1:116-126. https://doi.org/10.1080/23251042.2015.1008383

Mallinger RE, Gaines-Day HR, Gratton C (2017) Do managed bees have negative effects on wild bees? A systematic review of the literature. PLoS ONE 12(12):e0189268. https://doi.org/10.1371/ journal.pone. 0189268

Sirohi MH, Jackson J, Edwards M, Ollerton J (2015) Diversity and abundance of solitary and primitively eusocial bees in an urban centre: a case study from Northampton (England). J Insect Conserv 19:487-500

Steffan-Dewenter I, Tscharntke T (2000) Resource overlap and possible competition between honey bees and wild bees in Central Europe. Oecologia 122:288-296

Torné-Noguera A, Rodrigo A, Osorio S, Bosch J (2015) Collateral effects of beekeeping: impacts on pollen-nectar resources and wild bee communities. Basic Appl Ecol 17:199-209. https://doi. org/10.1016/j.baae.2015.11.004

Wojcik VA, Morandin LA, Adams LD, Rourke KE (2018) Floral resource competition between honey bees and wild bees: Is there clear evidence and can we guide management and conservation? Environ Entomol 47:822-833 